\title{
New vision, new goals, new markets? Reflections on a South African case study of community library services
}

\author{
Genevieve Hart' \\ Department of Library \& Information Science, University of the Western Cape \\ ghart@uwc.ac.za
}

\begin{abstract}
Received: 7 July 2010
Accepted: 10 November 2010

The article reflects on a case study of a group of six school-based dual use libraries in rural South Africa - focusing specifically on their community role. Its starting point is the library and information services (LIS) Transformation Charter's vision of public libraries that play a meaningful role in the attainment of the Millennium Development Goals. The study employed a mix of data gathering methodologies - interviews, observation and analysis of documents. The key question that emerges from the study relates to the rather low usage of the libraries by the adults in the surrounding villages. All six libraries claim to provide "access" but it is not clear what they provide access to. The study suggests that a sharper focus on their community information services is required. More leadership, staff education and focused programming might enable the libraries to fulfil their exciting potential.
\end{abstract}

Key words: Dual use libraries; community libraries; millennium development goals; rural libraries; South Africa

\section{Introduction}

This article reflects on a case study of six school-based public libraries in a remote ex-homeland region of South Africa. The aim is less to report systematically on the study, which will be done elsewhere (Hart 2010), than to examine it in terms of the vision of the Library and Information Services (LIS) Transformation Charter, an initiative of the National Council for Library and Information Services (2009). The Charter suggests that the Millennium Development Goals (MDGs) might frame dynamic developmental library services. The suggestion is that, if libraries build their services and programmes within the eight goals, they might extend their markets to reach beyond the limited minority they serve at present.

The six libraries were established with donor funding in $200 \mathrm{I}$ as part of a larger project of their province's public library service. The donor no longer funds the libraries and they operate under the provincial public library authorities. The initial aim of the case study, conducted in April 2009, was to investigate the value of dual or joint use libraries in the context of drastic shortages of both school and public libraries (Hart 2010). However, as the field study progressed, it became clear that the six dual use libraries were operating as school libraries serving a cluster of local schools rather more than as public or community libraries. It seems that few adults from the surrounding villages enter them. The focus of this article is not on their role as school libraries. The aim is rather to explore the questions the research provoked over the nature of library services for rural communities in South Africa. In common with all qualitative open-ended case studies, certain themes emerged in the course of the study, as will be shown in the account that follows.

\section{Public libraries in the South African context}

In common with other emerging and fast growing economies like Brazil, India and China, South Africa aspires to join the global knowledge society. But it is often described as a country with two economies. The first is on a par with the developed world; but the far larger second economy shares many of the same social and economic challenges as other sub-Saharan countries. University of Cape Town's (UCT) Development Policy Research Unit has described South Africa as "one of the most unequal societies in the world" (2010: 2). According to the Human Sciences Research Council, in $200 \mathrm{I}$ about $57 \%$ of South Africans were living below the poverty line income (Schwabe 2004). The Human Development Index (HDI) of the United Nations adds two factors to household income in its assessment of the quality of life of a country's citizens: life expectancy and education. Butler (2004: 66) points out that South Africa's HDI compares badly with many other countries with lower gross domestic products (GDPs). It comes $107^{\text {th }}$ out of 173 countries.

Poverty is about social exclusion as much as inadequate income. Poor people lack access to the resources that might aid their development. Butler (2004) makes no mention of libraries; but the premise that underlies this article is that community libraries are important, though underrated, developmental agencies. The case study in this article uncovers certain common issues related to the social mission of public libraries in a developing country. It provides pointers that

I. Genevieve Hart (PhD) is Associate Professor in the Department of Library and Information Science at the University of the Western Cape. 
might help make the Charter's vision of vibrant community library services a reality. The revitalisation of public library services is not just a South African imperative so it is hoped that this reflection might be of wider interest.

Compared with most other African countries, South Africa has a fairly well-developed public library infrastructure (Issak 2000). Each of its nine provinces has a library service placed within the provincial departments which report to the national Department of Arts and Culture; all but two of its municipalities have a library affiliated to the provincial services (Tlabela et al., 2007); and the major cities have their own metropolitan services. Despite the promising networks and structures, it might be argued that, as yet, South African public libraries have not fulfilled their potential role in social and economic development. The KPMG (2007) investigation of public libraries suggests that one of the reasons for their low membership is their inaccessibility. Most libraries are to be found in towns and their adjacent townships and there are hardly any in the ex-homeland regions. Another reason for their under-use could be that they just do not offer what people need or want. It seems, for example, that only 23 per cent are actively involved in literacy education - surely a basic function of public libraries. The author's research in 67 libraries in one rural province in 2005 found little evidence of development work or of cooperative projects with other development agencies in such fields as education, health or agriculture (Hart 2005: 157).

Given this comment, some might argue that the problem is that public libraries are not authentic community libraries. Aicheson (2006) distinguishes "community" libraries from "public" libraries by listing a set of norms for a community library. These include: a setting within a disadvantaged community; full participation of the community - including its management, staffing and funding; and an emphasis on "survival and citizens' action" information rather than on what she calls "recreational reading and viewing". These kinds of distinctions might be considered rather simplistic since public libraries, in all communities, clearly offer more than recreational reading. The developmental public library, as envisaged in the Library and Information Services (LIS) Transformation Charter (2009), has many of the attributes of the community library as described by Aicheson (2006). The Charter, indeed, consistently uses the term "community library" in all its references to government-funded public libraries. This article follows the example of the authors who see a community library as a public library that serves a smallish geographically delineated community (for example, McNicol 2006).

\section{The LIS Transformation Charter and the MDGs}

The Transformation Charter was commissioned in 2007 by the Department of Arts and Culture (DAC) and the National Council of Library and Information Services (NCLIS), a policy advisory body for the Ministers of Arts and Culture and of Education. The Charter is a component in the revitalisation of South African public libraries to which the DAC has allocated a grant of RI.3 billion and which began in 2006 with an investigation by KPMG into the status quo of public libraries. The grant shows government's commitment to public libraries, but the support is contingent on their playing a more dynamic role in the transformation of South African society. The Charter is the product of another nationwide investigation of all sectors of South African librarianship - a year or two after the KPMG study. Its outcome is a vision statement for South African libraries which includes the following statements:

- "The overarching social goal of LIS is to build the human, intellectual and social capital crucial to the knowledge society"; and

- "The model of LIS presented in the Charter is developmental, in keeping with the socioeconomic context and UNESCO's Millennium Development Goals".

The Charter's vision is that libraries will be "within reach of all", "places for everyone" and "forces for social cohesion and justice". While claiming to be encouraged by the work of the many dynamic public librarians in South Africa, the Charter's writers point out that less than 10 per cent of South Africans at present belong to public libraries, that they are unevenly distributed, that school learners account for 70 per cent of their usage, and that $\mathbf{7 4}$ percent of public libraries lack Internet access. It suggests that the contribution of libraries to social cohesion and development is not widely understood and that libraries are probably viewed by most South Africans as irrelevant collections of books for the educated, the middle class and students. Evidence in support of this claim might possibly lie in the destruction of five public libraries in so-called service delivery protests in the past year or two (Library and Information Association of South Africa 2010). The target of the protests was local authorities, but the fact that libraries were burned down could be symptomatic of the lack of value placed on them. The question might arise: How can South Africans value libraries if they lack access to them or have no use for them?

The Charter provides an answer to this question in its promotion of the developmental community library, which is geared to its community's social and economic development. The Charter suggests that MDGs could concretise its vision. The eight goals, together with clear benchmarks of progress, were formulated in global meetings in the early 1990s and are due for realisation by 2015. The United Nations reports progress towards their attainment in a number of 
websites, which provide both an overall picture and analysis by region and country. The goals are listed below, with comment selected from these sites on progress in sub-Saharan Africa and South Africa:

I. Eradicate extreme poverty and hunger. The goal is to halve the numbers living on less than $\$ 1.00$ a day.

2. Achieve universal primary education. Although numbers of primary school enrolments have increased in SubSaharan Africa since 2000, at $71 \%$ they still lag behind the global average of $90 \%$.

3. Promote gender equality and empower women. In many parts of Africa, girls are reported still to be more likely to drop out of school than boys.

4. Reduce child mortality. A child born in a developing country is still over 13 times more likely to die within the first five years of life than a child born in an industrialised country.

5. Improve maternal health. In sub-Saharan Africa, a woman's risk of dying from treatable or preventable complications of pregnancy and childbirth over the course of her lifetime is $I$ in 22, compared to $I$ in 7,300 in the developed regions.

6. Combat HIV/AIDS, malaria. Every day, across the world, nearly 7,500 people become infected with HIV and 5,500 die from AIDS, mostly due to a lack of HIV prevention and treatment services. However, as the use of antiretroviral drugs grows, people are living longer. The vast majority of those living with HIV are in sub-Saharan Africa.

7. Ensure environmental sustainability. Although the developed countries are responsible for more damage to the planet's environment, Africa's geography and its prevailing poverty make it particularly vulnerable to global warming.

8. Global partnership for development.

The last goal includes the sharing of the benefits of ICTs, across developed and developing countries and across public and private sectors. It is claimed that providing Internet connectivity to the developing world will help realise goals for health, education, employment and poverty reduction. The digital divide is still wide. In developed countries, 58 per cent of the population was using the Internet in 2006, compared to II per cent in developing countries and only one per cent in the least developed countries (United Nations 2008). At present, less than six per cent of South Africans have access to the Internet at home (Tlabala et al., 2007). There is consensus that the aspirations of emerging economies like South Africa, Brazil, India and China to join the ranks of the developed countries will depend on their "informatisation" or what the sociologist Manuel Castells (2004) calls "informationalism" - that is, on the provision of easy access to information and knowledge by means of information and communications technologies (ICTs). Castells (2004) critiques the common notion of the "information society" in pointing out that information and knowledge have always been sources of power and wealth. What is different in today's "network society" is that the power is embedded in technologies. The notion of communications networks implies the possibility of disconnection - some people are excluded from them because they do not have the required technologies. Development is thus reliant on technology. Castells (1998) warns of the dangers of an excluded and alienated "fourth world". He claims that Informationalism is "intertwined with rising inequality and social exclusion throughout the world" (1998: 69). The same comment might of course be applied to a single country such as South Africa where the divides are so wide.

If then the digital divide reflects the broader development divide, then the importance of the role of public libraries in bringing rural and other marginalised communities into the global information society is clear. This potential has been recognised by people outside librarianship, as evidenced in 2007 in the Human Sciences Research Council's investigation of South Africans' access to ICT (Tlabela et al., 2007). The investigation mapped various public ICT service centres and concludes that public libraries should take the lead in bridging digital divides for the following reasons:

- Public libraries have a larger footprint than other public ICT service centres. Most municipalities have a public library service.

- Information is the core business of libraries. They are community information sources.

- Libraries do more than just provide ICT facilities; they add value by means of their educational programmes which teach "information management skills". These are what librarians would call "information literacy".

- Libraries develop literacy which the authors see as an "essential skill to unlock the information and opportunities of the Internet".

A perusal of the conference and journal papers of the Library and information Association of South Africa (LIASA) over the past few years shows a growing awareness amongst librarians of the need to build community services relevant to developing communities. Recent LIASA conference titles, for example, include: in 2006, "Libraries: Partners in Learning, Nation Building and Development"; in 2005, "Taking Libraries to the People"; in 2004, "Libraries and Democracy: The Vital Link"; and in 2003, "Tsoga o itirele: Libraries as Agents of Change". Scattered among the conference papers each year there are reports of innovative community projects that extend beyond the walls of the library. There is moreover a

SA Jnl Libs \& Info Sci 2010, 76(2) 
strand of research from the early 1990s on the information needs of rural people (for example Fairer-Wessels 1990; Mchombu 200I).

The author has made the point before in her discussion of social capital (Hart 2007) that the LIS profession would do well to use the same language as economists and politicians. If development and service delivery are the South African imperatives, then the profession must take part in the discourse of development. The suggestion in the LIS Transformation Charter is that the MDGs provide a helpful framework for transformed library and information services. By explicitly linking their services to the MDGs, public libraries' role in social and economic development will be recognised, as well as their connections to other social agencies. Services and programmes might be planned around each of the eight goals, since the traditional work of libraries in education, information, communication and knowledge building is vital to each. Kaniki (2008: 25) borrows the table which Forsyth produced in a paper in 2005, which analyses libraries' roles in terms of the eight goals.

\section{Case study findings and reflections}

The preceding discussion sketches the background of the case study of six school-based community libraries in rural South Africa. The LIS Transformation Chapter endorses dual use libraries to fill the huge gaps in school and public library services in South Africa, with the proviso that service to each user community is not compromised. As McNicol, an expert on dual use libraries, puts it, "The joint use library must be better than the sum of its parts" (2006: 519). Bundy (2003) shows the value of dual use libraries in scarcely populated rural communities in parts of Australia. It makes economic sense to place publicly-funded public libraries in already existing publicly-funded school libraries. Rural districts, he points out, might not have public libraries but they generally have schools.

The researcher relied on two authors as she drew up her research questions: Haycock and McNicol, who both published reviews of dual use libraries in 2006. Haycock reviews research in dual use school community libraries in the United States, Canada, Australia and New Zealand to come up with 10 predictors of success:

- user communities of a manageable size - fewer than 10,000;

- a formal planning process involving the stakeholders;

- written legal agreements on governance, administration, finances, assessment and termination;

- a single decision-making committee representing all stakeholders which develops policies and procedures;

- visible and convenient location, accommodating a variety of groups and a separate area for adults;

- connections to a larger network or regional system;

- a strong desire for success and support among the principal and teachers;

- one highly motivated professional librarian in charge, preferably qualified in both education and librarianship;

- regular discussion and communication between public library staff and school staff; and

- no restrictions on access to resources or on the circulation of materials.

McNicol's synthesis of research in the United Kingdom (2006) is of particular value for this report as it looks at dual use libraries from the perspective of their public users. Her list of success factors overlaps with Haycock's (2006), but she emphasises the two crucial factors of community consultation and an ethos of service shared by both public library and school library role-players. Her survey of the controversies related to dual use reveals that the most common objections from public users relate to geographic position, access and size. She warns that conflict can arise from differences in ethos - for example, school libraries are places of quite formal teaching and study, whereas public libraries tend to aim for an ambiance of leisure and culture (2006: 527). Despite the challenges, McNicol (2006) sees joint use libraries as beneficial for the public just because of their closeness to the school community. She quotes examples of how they facilitate family learning, lifelong learning and intergenerational interaction. Thus the school itself becomes a dynamic focal point for the generation of a community's social and intellectual capital.

\subsection{Research questions}

Although the introductory background discussion and the above predictors of success inform the case study, it began with an open mind. Most of the existing research assumes first world conditions and so might not apply in rural South Africa. The author began her data gathering with one broad question in mind: "How do these dual use libraries work?" But behind that question lay the desire to look for insights they might offer for the LIS Transformation Charter's vision of dynamic developmental community services, which was outlined earlier.

A case study is the study of a single entity or phenomenon, within a defined period and using a variety of data collection techniques. The six case study libraries are closely connected with one another, as evidenced in the camaraderie and constant communication among the six librarians. They are viewed as a unit by the provincial library service, as shown in their winning of that library service's "Community Library of the Year" award in 2007. Two criteria were used by the donor in the choice of the school sites: their remoteness and the existence of a library room. 
The author spent two weeks in the area in April 2009. The case study coincided with South Africa's Library Week and all six libraries, in common with all libraries in their province, had put displays of books up just inside their libraries, all with the 2009 slogan “Welcome @ your library. SA Library Week. Access for all at your library”. This slogan with its use of the concept of "access" emerged as a thread that runs through the description of the study and analysis of its data that follow in later sections.

Six days were spent in one of the libraries and the second week comprised visits to the other five libraries, interviews with their management and gathering of relevant documents. A mix of data-gathering methods was used:

- analysis of documents such as policies and memoranda of agreement ;

- visits to the school community libraries to document conditions and interview their staff;

- interviews - with the library staff, public library and education department officials and managers, principals and teachers, and a community member of one of the library committees; and

- observation in one library. The workings of the library in the school day and afterwards over one week were documented in photographs and field notes. Participation in the life of the library hopefully unpeeled the realities as experienced by key role-players in the school and community.

Some limitations have to be acknowledged. The long distances between sites and poor roads meant that the visits to five of the schools were too brief. One week was too short a time for an in-depth ethnographic field study in the chosen site. However, the interviewing in the week-long stay in that site was, in qualitative terminology, "iterative", which allows for more in-depth exploration. Thus the librarian in this school sat down for three formal interviews and in the course of the week engaged in much informal chat. Follow-up clarifying phone calls and email messages continued once the author had returned home. Triangulation across the various data types allowed for the emergence and corroboration of themes.

The challenge in the reporting of qualitative research is always to make sense of the mounds of data that accumulate. The solution in the account that follows is to follow Wolcott's process of description, analysis and interpretation (1994). He points out, however, that even seemingly straightforward description is "theory-laden" (p. 13). Thus, the researcher chooses what to include or exclude - guided by the themes in the literature and the data categories that formulate in his or her mind.

\subsection{Case description}

The socio-economic conditions in the area are probably fairly representative of the former apartheid era "homelands" or Bantustans. The homelands never came close to economic self-sufficiency or political legitimacy. As the political scientist Butler (2004: 135) points out, many are not "rural" at all but rather immense and densely peopled townships placed far from economic opportunities. The case study site, now integrated into one of South Africa's nine provinces, is the poorest region in its Province. The author's photographs attest to the degradation of the land and the prevailing poverty - as well as to the mountainous beauty of the region. It is now divided between two municipalities and its 910 square kilometres (565 sq miles) area is home to about I.3 million people. The central business district is crammed with shops, banks, street stalls, taxi ranks and municipal buildings. In the central business district, there are two libraries - a large central building and a smaller children's library. Both were beneficiaries in $200 \mathrm{I}$ of the same donor that established the school community libraries, using the funds to build study rooms and toy libraries.

Once out of the busy downtown streets, street names disappear and the roads revert to rough stone and sand. Because of the poor transport infrastructure and the wide scattering of the population, access to the central library is difficult. This is why in $200 \mathrm{I}$ the provincial public library service approached the international donor for help in setting up six community libraries in remote schools. The six libraries are about 50 minutes drive away from the business and commercial hub. Kombi taxis are the main means of transport. Their high fares are not the only problem, as evidenced in the comment from one participant that she may sit downtown for two hours waiting for her taxi home to fill up with passengers. The provincial library service pays the salaries of the six librarians in charge, who report to a district manager, stationed in a town some 80 kilometers distant. The author has chosen to use the title "librarian", although all of them are in fact classified as "library assistants" by their province. Only one has a formal librarianship qualification, a National Diploma in LIS; three have teaching diplomas and one has a National Diploma in Public Relations. At the time of the study, each of the six libraries also had two "interns", contracted to the local authority, but there was uncertainty over their future.

The positions of the libraries on their campuses are significant in terms of the accepted criteria for community libraries. Only one is clearly visible from the school gate and could conform in terms of community access. One is situated right at the back of its campus and is reached by a muddy path overrun by long grass; another is reached by a narrow circular dark staircase; another is at the furthest upstairs corner of its school, two blocks in from the school entrance. None has any sign at the school gates. It is perhaps noteworthy that the Library Week displays with their marketing messages, which were mentioned above, were all inside the libraries and so invisible. 
Despite the similar interior layouts, to an outside observer each library is different - largely due to furnishings, quantity of resources and position in the school. In one library, the author's photographs record youths stooping over chess boards on the floor since that library has only one large table in its reference section; and two have old-style double school desks. Photographs record the sparsely stocked shelves in most of the six libraries. The original donor funded the start-up collections and the toy libraries and since then the provincial library service has been largely responsible for the collections. The provincial Education Department's school library service provided each school with a computer and its cataloguing system, but only provides the occasional box of books to the schools. In theory, schools are expected to allocate a portion of their annual budgets to their libraries, but the reality is that only one of the six schools provides an occasional small sum for the library. The librarians catalogue and shelve the Education Department books separately from the public library books - claiming that the merging of the two collections would confuse the annual public library stock take.

At the time of the study no books from either collection were allowed out of the libraries. This policy, apparently, has changed since, after the installation of the provincial library service's circulation system. The study suggests how this policy must have impacted on the traditional library role of encouraging reading. The chief reading activity for the groups of students sent to the library in the course of the day appears to be skimming magazines; and the women in an adult literacy class, who are sent across to the library most days to sit and read, just choose any book from the Easy Readers section, read a few pages and leave it unfinished when they have to go back to their classroom. On the author's querying the lending policy, the Media Learning Facilitator from the Education Department defends it as follows, "But to have anybody from the community walk in and want to take books out, I think that must be quite nerve racking."

\section{Case study analysis}

Certain themes emerged in the course of the study - as is expected in qualitative research. The chief of these, as mentioned earlier, is the issue of "access". The concept has at least two layers of meaning in relation to the case study libraries as community libraries. The first has already been referred to - geographic accessibility. But the second is more complex. On being confronted every day with the Library Week slogan "Access for all @ your library", the researcher became preoccupied with the question: "Access to what?" She began to consider what the libraries in fact offer that could attract adults from the surrounding villages.

The study began with an examination of the provincial public library's motivating document for the project, which was presented to the donor in $200 \mathrm{I}$. It describes the aims as:

- increasing numbers of libraries and bringing them closer to the people;

- providing electronic access;

- broadening the scope of services offered; and

- teaching people how to use information to their benefit, thus creating an environment supportive of sustained economic, social and civic development.

These aims are clearly in line with the vision of the developmental community library as described earlier. The document spells out quite precise expected outcomes with regard to their public users, for example: increasing library membership by 20 per cent; increasing literacy rates by five per cent; and increasing by 20 per cent the number of people accessing government and community information. As far as the author knows, there has been no attempt to measure if these outcomes are being achieved. It has to be said that there are no systems in place that would enable measurement. For example, the libraries keep no membership files which might record reading habits; at the time of the study, books were not being issued out of the library so circulation figures could not be compared; no before-and-after literacy study has been undertaken; and no rigorous community surveying is apparent.

However, the fact that the Provincial LIS continues to support the libraries after the withdrawal of the donor must indicate confidence that its money is being well-spent. The author's photographs and field notes document the value of a dual use library. For example, a photograph taken on the first morning shows the diversity of users: a small group of school learners sitting at the reference table paging though science texts; two youths stooped over a chess board; a young community worker being helped by the library intern to print out his monthly report for his NGO; a group of six adult learners sitting reading; and a nursery school class in for a storytelling session.

Interviews with the libraries' staff reveal a passionate belief in the value of their work. Thus one claims proudly that he "was born to a librarian". His passion for his work and his pride in being a role model and leader in his community are evident in the following extracts:

I feel, to be a librarian ... I'm passionate about it. Yes, that gives me a passion, because if you talk about the library, my ears are open and I have to listen attentively towards what you are saying about the library. Even if 
there is something wrong or misinterpretation, so I have to correct. I have to make sure that I correct the very same person and motivate the person towards, to use the library. Yes, l'm really passionate about this position. We have to try to know almost everything from your community, so that when someone comes from outside they have to see someone who knows everything about your community. You have to be a leader, yes, yes.

Yes. You know, I'm happy to be here because to be a teacher you become a role model of your community. So some of community should believe in you because you have to provide an excellent service towards them. So to be a librarian I can compare that the position ... as being a teacher.

The lack of easy and visible access, which was described earlier, might partly explain the rather low usage of the libraries by the adults in the surrounding villages that was documented over the two weeks of the study. Observation in the course of the week in one library recorded a steady trickle of young people, recent school-leavers still out of work and NGO workers. They come in to read the newspapers and magazines, play chess, look up information on the Internet, type up reports and learn computer skills. Two other regular groups are a small group of women in a literacy class hosted by the school and a nursery school group who play with the toys and listen to stories.

Another explanation for the rather low use might lie in McNicol's comment that public users often feel uncomfortable in the company of groups of teenagers free of teacher supervision (2006: 528). The original service level agreement reveals that the original plan was for the libraries to act as school libraries in the morning and to be open to the community after school hours. However, observation shows community members coming in rather in the mornings, which are rather quiet, with students from nearby schools dominating the afternoons. Yet another factor could be doubts inside the schools over community use. Interviews and observation uncover some ambivalence inside the schools over their dual role as community libraries - although this was denied in the formal interviews with educators and principals. This librarian acknowledges that the school is not always welcoming towards the community in his comment:

The school wants to run the library; they want to own the library. Whereby they don't sometimes want the community to use the library ... It's a problem still existing, yes. Because sometimes you'll find that the gates are closed. You'll try to ask sometimes same question, why the gates are closed, but they tell you that it's because children during school hours want to dodge the classes.

However, the case study suggests that probably the fundamental reason for the low use is that people in the community do not have a use for the library - or at least do not perceive a use. The Public Library District Manager acknowledges the low use by adults and attributes it to the prevailing "culture", saying:

It's mostly used by the schools. But you know it's something that happens in our black communities. They the adults are not using libraries. We are still trying to teach them that they use libraries for all their information needs. But it's the culture that is going on in our black community.

Here, she lends support to the author's earlier research in a neighbouring province that found a philosophical acceptance among librarians that rural public libraries at present are used almost solely by young people, for their school or tertiary education (Hart 2006). In apartheid South Africa, blacks, especially those outside the urban areas, had little chance of building a culture of library use - either school or public. One of the case study participants, a school principal, highlights this in her allusion to her rural childhood experience:

No, we were in the disadvantaged areas where libraries were too far from where we stayed. Because in the rural areas, the use of a library, it was not something that was in mind, or that we were making aware of it. So, but nobody at that time used to tell us about anything about the library.

The Education Department's Media Learning Facilitator echoes the public library manager in her comment on the prevailing lack of reading or library "culture":

l've never seen an elderly or middle aged person here, idly browsing through a book ... Because maybe that culture, they didn't have that culture when they were growing up.

Her words bring to mind Acheson's distinction between a community library and a public library that was referred to earlier (2006). Browsing "idly" through a book is perhaps just not to be expected. 
One librarian acknowledges in the following words that he has as yet failed to get people in the surrounding village to come to the library:

They don't use the library, yes. We try to give them things that will motivate them to the library. We give them the magazines, give them things that you'll think they're not longer useful for the library. Things that you'll say will benefit them.

I got the taxi here, use my feet towards the library, it's about $900 \mathrm{~m}$, about a kilometer. I meet with these two ladies on the left hand side. Talk to them. They will tell you they are busy maybe meet them next time. Then you go to other people maybe you give them pamphlets about the library. You invite them to the library. But then you won't even see one person in that month.

His words lead back to the question of the mission of a community library in rural South Africa and to the question "Access to what?" which was posed earlier. The following extract from an interview with one of the librarians might be relevant:

G Hart: But maybe they think of the library as being a place for literate educated people? They don't realise the library can help them?

Librarian: Genevieve Hart, do you see where TM [village] starts? (Yes) First house, you may enter that house and ask whether those people know about the library. They will tell you yes, they know where the library is, they know that their children attend the library. And then go to the last house when this village ends, they know about the library. I marketed to the village enough.

He believes he has done his best to market the library by walking house to house and by talking on community radio. The author indeed accompanied him on a pleasant marketing visit to the local clinic where he gave out flyers about Library Week to the staff. He might well be correct in his claim that people "know about" the library. But knowing about the library does not mean that they will use it. His talk of marketing the "library" in the surrounding villages is rather vague. It does not suggest a clear conception of what he is selling and why people might buy it.

\section{Discussion of findings}

In considering what meaning might be constructed from the preceding account, the concept of the community library must be returned to. When the six libraries are viewed in the light of the theory of dual use in the literature, certain shortcomings are evident, especially from the perspective of the community. The theory that says the joint use library must be better than the sum of its parts might not yet quite be true of the case study libraries.

The Public Library District Manager was quoted above as saying "We are still trying to teach them [South Africans] that they use libraries for all their information needs" but the author could find little evidence of this teaching. Aicheson's mention of community libraries' focus on "survival and citizens' action" information and on their repackaging of information comes to mind (2006). All six libraries have on their walls NGO and government posters on topics like HIV/ AIDS and tuberculosis, and they have local and provincial government notices and reports on their government shelves but that seems to be the extent of their community information services.

One of the pitfalls that McNicol (2006: 527) identifies in the dual use model is the difference in ethos between public and school librarianship. She claims that in the United Kingdom public libraries model themselves on book shops, which might be incompatible with the educational mission of a school library. However, a consideration of the case study context suggests that the public and school user groups would have similar expectations. Education, formal and informal, probably is what the surrounding communities would look for in the libraries.

McNicol's review of dual use libraries as community libraries (2006) highlights the importance of consultation with the community. The study found no evidence of consultation with people in the surrounding communities to find out what they might expect of the library. On paper the libraries have steering committees, but they appear to be more or less dormant.

\section{Conclusions}

In defense of the case study libraries, it has to be said that the focus in this article has been on the libraries' community services. The author found evidence of much more proactive effort in their work with educators and learners, which has been described in another article (Hart 2010). The fundamental question of the study asks if dual use libraries might offer a useful model for South Africa, given the backlogs in both school and public library provision. Overall, it is clear that, 
despite the contradictions and shortcomings, the libraries are an admirable attempt to serve the school-going and youth population in a rural area of South Africa and, to a limited extent, its adult communities.

The shortcomings in their community role are made clear in the preceding account. As stated in the introduction, South African librarians have since the 1980s claimed to offer vital and relevant community services. But the case study serves to raise questions over the gap between rhetoric and reality. The librarians on the ground cannot be expected to take sole responsibility for extending their services deeper into their communities. Where should they start? International research has found that inadequately educated staff can reduce the effectiveness of rural libraries (for example Luchs $200 \mathrm{I}$ ). Staff on the ground need insight into the social mission of community libraries as well as technical skills (Hart 2005: 264).

Leadership, programming, staff education and guidance are surely required. This article began with the vision of the LIS Transformation Charter for more dynamic library services, which might be meaningful for the average South African. It then went on to outline the MDGs, which, it suggests, might offer LIS programme planners somewhere to start. They offer a frame for library services and for cooperation for other developmental agencies.

The present rather low usage of the case study libraries by the public, which is acknowledged by all participants, might raise the question of sustainability. The libraries are, after all, funded by the public library service, which falls under a different provincial department from the schools and the school library services. But the author believes that the dual use libraries represent an innovative and generous decision on the part of the provincial public library service to step into library gaps. They offer a useful learning opportunity for the development of community libraries in rural South Africa.

\section{References}

Aicheson, J. 2006. Experiments in the provision of rural community libraries in South Africa: the Family Literacy Project's initiatives. Innovation, 32. [Online]. http://www.familyliteracyproject.co.za/pdf/FLPCommunityLibraries/nnovation32.pdf. Accessed 19 October 2008.

Bundy, A. 2003. Joint use libraries: the ultimate form of cooperation. In: McCabe, GB \& Kennedy JR. (eds). Planning the modern public library building. Westport, СT: Libraries Unlimited, pp. I29-I46. [Online]. http://www.library.unisa.edu.au/about/papers/ jointuse.pdf. Accessed 30 January 2010.

Butler, A. 2004. Contemporary South Africa. Basingstoke: Palgrave Macmillan.

Castells, M. 1998. End of millennium, the Information Age: economy, society and culture Vol. III. Cambridge, MA: Blackwell.

Castells, M. 2004. Informationalism, networks and the network society. In: Castells, M. (ed.) The Network society. Northhampton, Mass: Edward Elgar, pp. 3-7; 37-45.

Center for Knowledge Societies. 2008. Emerging economy report. [Online]. http://www.emergingeconomyreport.com/table-ofcontents/. Accessed 30 October 2010.

Department of Arts \& Culture. 2007. Audit. Pretoria: Author.

Issak, A. (ed.) 2000. Public libraries in Africa: a report and annotated bibliography. Oxford: International Network for the Availability of Scientific Publications.

Fairer-Wessels, F. 1990. Basic community needs of urban black women in Mamelodi, Pretoria, South Africa. South African Journal of Library and Information Science, 58(4): 359-369.

Hart, G. 2005. The readiness of public libraries in South Africa for information literacy education. The case of Mpumalanga Province. PhD dissertation, University of Cape Town.

Hart, G. 2006. The information literacy education readiness of public libraries in Mpumalanga Province (South Africa). Libri, 56(I): 48-62.

Hart, G. 2007. Social capital: a fresh vision for public libraries in South Africa? South African Journal of Libraries and Information Science, 73(I): 14-24

Hart, G. 2010. The tricky business of dual use libraries: a case study in rural South Africa. Forthcoming.

Haycock, K. 2006. Dual use libraries: guidelines for success. Library Trends, 54(4): 488-500.

Kaniki, A. 1995. Exploratory study of information needs in the Kwa-Nganese (Natal) and Qumbu (Transkei) communities of South Africa. South African Journal of Library and Information Science, 63(I): 9- 17.

Kaniki, A. 2008. Libraries and information service in facilitating knowledge production and management for the Millennium Development Goals. In: Njobvu, B \& Koopman, S. (eds). Libraries and information services towards the attainment of the UN Millennium Development Goals. München: K G Saur, pp. 15-27.

KPMG. 2007. Report on the investigation into the development of public/community libraries in South Africa. Phase 2: Status Quo report. Pretoria: Department of Arts \& Culture.

Library and Information Association of South Africa. 2010. LIASA condemns the brning down of libraries. Press statement February II 2010. [Online]. http://list.liasa.org.za/pipermail/liasaonline/2010-February/002592.html. (Accessed 24 June 20I0).

Library and information services (LIS) transformation charter. 6th draft. 2009. Pretoria: Department of Arts and Culture (DAC) and National Council for Library and Information Services (NCLIS). [Online]. http://www.dac.gov.za/publications/reports/2009/ Transformation\%20charter-6th\%20draft-22 102009.pdf. (Accessed 31 January 2010).

Luchs, M. 200I. The education of the rural librarian: advantages and obstacles. Rural Libraries, 2I(I): 5 I-64.

Mchombu, K. 200I. Research on measuring the impact of information on rural development. In: Stilwell, C, Leach, A \& Burton, S. (eds). Knowledge, information and development: an African perspective. Scottsville: School of Human \& Social Studies, University of Natal (Pietermaritzburg), pp. 229-238.

McNicol, S. 2006. What makes a joint use library a community library? Library Trends 54(4): 5I 9-534.

SA Jnl Libs \& Info Sci 2010, 76(2) 
Nassimbeni, M \& May, B. 2006. Adult education in South African public libraries: a profile of activities. South African Journal of Libraries and Information Science, 72(1): I2-19.

National Education Policy Investigation. Library and Information Services Research Group. 1992. Library and information services: report of the NEPI Library and Information Services Research Group: a project of the National Education Co-ordinating Committee. Cape Town: Oxford University Press / NECC.

Schwabe, C. 2004. Fact sheet: poverty in South Africa. Pretoria: Human Sciences Research Council. [Online]. http:// www.sarpn.org.za/documents/d0000990/. (Accessed 30 June 20I0).

Tlabela K, Roodt, J, Paterson, A \& Weir-Smith, G. 2007. Mapping ICT access in South Africa. Cape Town: HSRC Press. [Online]. http://www.hsrcpress.ac.za/full title info.asp?id=2192. (30 April 2009).

United Nations. 2008. The millennium development goals report 2008. New York: United Nations. [Online]. www.un.org/ millenniumgoals/.../The\%20Millennium\%20Development\%20Goals\%20Report\%20200pdf. (Accessed 30 April 2009).

University of Cape Town. Development Policy Research Unit. 2010. Income and non-income inequality in post-apartheid South Africa: what are the drivers and possible policy interventions. Cape Town: University of Cape Town.

Wolcott, H F. 1994. Transforming qualitative data: description, analysis, and interpretation. Thousand Oaks, CA: Sage.

Zaaiman, RB., Roux, PJA \& Rykheer, JH. 1988. The use of libraries for the development of South Africa: final report on an investigation for the South African Institute for Librarianship and Information Science. Pretoria: Centre for Library and Information Service, Department of Library and Information Science, University of South Africa. 